\title{
Anaerobic oxidation of short-chain alkanes in hydrothermal sediments: potential influences on sulfur cycling and microbial diversity
}

\author{
Melissa M. Adams ${ }^{1}$, Adrienne L. Hoarfrost ${ }^{2}$, Arpita Bose ${ }^{1}$, Samantha B. Joye ${ }^{3}$ and Peter R. Girguis ${ }^{1}$ * \\ ${ }^{2}$ Department of Organismic and Evolutionary Biology, Harvard University, Cambridge, MA, USA \\ ${ }^{2}$ Department of Marine Sciences, University of North Carolina at Chapel Hill, Chapel Hill, NC, USA \\ ${ }^{3}$ Department of Marine Sciences, University of Georgia, Athens, GA, USA
}

\section{Edited by:}

Andreas Teske, University of North Carolina at Chapel Hill, USA

\section{Reviewed by:}

Julie A. Huber, Marine Biological Laboratory, USA

Elizaveta Bonch-Osmolovskyaya, Winogradsky Institute of Microbiology Russian Academy of Sciences, Russia

\section{*Correspondence:}

Peter R. Girguis, Department of Organismic and Evolutionary Biology, Harvard University, Biological Laboratories, Room 3085, 16 Divinity Avenue, Cambridge, MA 02138, USA. e-mail:pgirguis@oeb.harvard.edu
Short-chain alkanes play a substantial role in carbon and sulfur cycling at hydrocarbonrich environments globally, yet few studies have examined the metabolism of ethane $\left(C_{2}\right)$, propane $\left(C_{3}\right)$, and butane $\left(C_{4}\right)$ in anoxic sediments in contrast to methane $\left(C_{1}\right)$. In hydrothermal vent systems, short-chain alkanes are formed over relatively short geological time scales via thermogenic processes and often exist at high concentrations. The sediment-covered hydrothermal vent systems at Middle Valley (MV, Juan de Fuca Ridge) are an ideal site for investigating the anaerobic oxidation of $\mathrm{C}_{1}-\mathrm{C}_{4}$ alkanes, given the elevated temperatures and dissolved hydrocarbon species characteristic of these metalliferous sediments. We examined whether MV microbial communities oxidized $\mathrm{C}_{1}-\mathrm{C}_{4}$ alkanes under mesophilic to thermophilic sulfate-reducing conditions. Here we present data from discrete temperature $\left(25,55\right.$, and $75^{\circ} \mathrm{C}$ ) anaerobic batch reactor incubations of MV sediments supplemented with individual alkanes. Co-registered alkane consumption and sulfate reduction (SR) measurements provide clear evidence for $\mathrm{C}_{1}-\mathrm{C}_{4}$ alkane oxidation linked to SR over time and across temperatures. In these anaerobic batch reactor sediments, $16 \mathrm{~S}$ ribosomal RNA pyrosequencing revealed that Deltaproteobacteria, particularly a novel sulfate-reducing lineage, were the likely phylotypes mediating the oxidation of $\mathrm{C}_{2}-\mathrm{C}_{4}$ alkanes. Maximum $\mathrm{C}_{1}-\mathrm{C}_{4}$ alkane oxidation rates occurred at $55^{\circ} \mathrm{C}$, which reflects the mid-core sediment temperature profile and corroborates previous studies of rate maxima for the anaerobic oxidation of methane (AOM). Of the alkanes investigated, $\mathrm{C}_{3}$ was oxidized at the highest rate over time, then $\mathrm{C}_{4}, \mathrm{C}_{2}$, and $\mathrm{C}_{1}$, respectively. The implications of these results are discussed with respect to the potential competition between the anaerobic oxidation of $\mathrm{C}_{2}-\mathrm{C}_{4}$ alkanes with $\mathrm{AOM}$ for available oxidants and the influence on the fate of $\mathrm{C}_{1}$ derived from these hydrothermal systems.

Keywords: hydrothermal vent, metalliferous sediments, Juan de Fuca Ridge, short-chain alkanes, sulfate reduction

\section{INTRODUCTION}

Hydrocarbon gases, including methane $\left(\mathrm{C}_{1}\right)$, ethane $\left(\mathrm{C}_{2}\right)$, propane $\left(\mathrm{C}_{3}\right)$, and $n$-butane $\left(\mathrm{C}_{4}\right)$, are produced via thermogenic and biogenic processes in the deep subsurface and are substantial components of the organic carbon pool across marine and terrestrial ecosystems (Joye et al., 2004; Milkov, 2005; Cruse and Seewald, 2006; Hinrichs et al., 2006; Savage etal., 2010). Over the past decade, studies focused on the anaerobic oxidation of methane (AOM) revealed the functional potential, ecological physiology, and diversity of microorganisms mediating this process and the global distribution of $\mathrm{AOM}$ as an effective benthic filter that reduces methane emissions into the oceans and atmosphere (for reviews, see Conrad, 2009; Knittel and Boetius, 2009; Valentine, 2011). In contrast, the anaerobic oxidation of long-chain alkanes $\left(>\mathrm{C}_{6}\right)$ and aromatics has also been studied extensively resulting in the isolation of several bacteria, such as sulfate-reducing bacteria (SRB) that oxidize crude oil anaerobically (Van Hamme et al., 2003). There is a gap in our understanding of the metabolism and fate of non-methane, short-chain $\left(\mathrm{C}_{2}-\mathrm{C}_{4}\right)$ alkanes in deep sea sediments. Furthermore, there is growing interest in determining the extent to which microorganisms mediate the anaerobic oxidation of $\mathrm{C}_{2}-\mathrm{C}_{4}$ alkanes, as many studies have indicated that the degradation of these aliphatic hydrocarbons may be linked to global biogeochemical cycles (Lorenson et al., 2002; Formolo et al., 2004; Sassen et al., 2004; Milkov, 2005; Bowles et al., 2011; Quistad and Valentine, 2011).

Recently, SRB from hydrocarbon seep sediments of the Gulf of Mexico and Guaymas Basin - both of which are environments rich in short-chain alkanes - were documented to oxidize short-chain alkanes to $\mathrm{CO}_{2}$ anaerobically (Kniemeyer et al., 2007). Different temperature regimens $\left(12,28\right.$, and $\left.60^{\circ} \mathrm{C}\right)$ along with multiple substrates were tested and a pure culture (deemed BuS5) was isolated from mesophilic enrichments with $\mathrm{C}_{3}$ or $\mathrm{C}_{4}$ as the sole exogenous carbon source. Through comparative sequence analysis, strain BuS5 was determined to cluster with the metabolically diverse Desulfosarcina/Desulfococcus (DSS) cluster, which also contains the 
SRB found in consortia with anaerobic methanotrophs (ANME) in seep sediments. Enrichments from a terrestrial, low temperature sulfidic hydrocarbon seep corroborated the biodegradation mechanism of complete $\mathrm{C}_{3}$ oxidation to $\mathrm{CO}_{2}$ with most bacterial phylotypes surveyed belonging to the Deltaproteobacteria, particularly within the family Desulfobacteraceae (Savage et al., 2010). Cold adapted $C_{3}$ and $C_{4}$, sulfate-reducing cultures have also been obtained from Gulf of Mexico and Hydrate Ridge sediments with maximum rates of SR between 16 and $20^{\circ} \mathrm{C}$ and dominant phylotypes allied to the DSS cluster including BuS5 (Jaekel et al., 2012). In the study by Kniemeyer et al. (2007) $\mathrm{C}_{4}$ alkane degradation linked to sulfate reduction (SR) was not quantified at thermophilic temperatures, buta Guaymas Basin sediment enrichment with $\mathrm{C}_{3}$ at $60^{\circ} \mathrm{C}$ was dominated by Gram positive bacteria most closely allied to the Desulfotomaculum. Moreover, there was no evidence for $\mathrm{C}_{2}$ degradation in mesophilic $\left(28^{\circ} \mathrm{C}\right)$ or thermophilic $\left(60^{\circ} \mathrm{C}\right)$ enrichments or $\mathrm{C}_{2}$-linked SR (albeit, there was very slow $\mathrm{C}_{2}$-dependent $\mathrm{SR}$ in Gulf of Mexico enrichments at $12^{\circ} \mathrm{C}$ after $>200$ days).

The Middle Valley (MV) hydrothermal vent field - located on the northern Juan de Fuca Ridge - is an ideal environment for investigating mesophilic to thermophilic anaerobic oxidation of $\mathrm{C}_{2}-\mathrm{C}_{4}$ alkanes, given the elevated temperatures and dissolved hydrocarbon species characteristic of these sediments (Goodfellow and Blaise, 1988; Davis and Fisher, 1994; Cruse and Seewald, 2006). Deep sea hydrothermal vents are complex and dynamic habitats characterized by steep thermal and chemical gradients, a diverse array of carbon and energy sources, and high concentrations of dissolved volatiles (Butterfield et al., 1990, 1994; Von Damm et al., 1995). In the MV system, hydrothermal vent fluids interact with overlying sediments and the thermal alteration of sedimentary organic matter results in the production and/or release of a number of carbon sources, including shortchain alkanes (Cruse and Seewald, 2006; Cruse et al., 2008; Cruse and Seewald, 2010). These hydrothermally influenced sediments also contain high concentrations of reduced compounds, such as $\mathrm{H}_{2}$ and hydrogen sulfide $\left(\mathrm{H}_{2} \mathrm{~S}\right.$; Ames et al., 1993; Rushdl and Simonelt, 2002), and metals and metal sulfides at various reduced and oxidized states (Goodfellow and Blaise, 1988; Ames et al., 1993; Wankel et al., 2012). In contrast to the extremely organic-rich sediments of other sedimented hydrothermal systems, e.g., the Guaymas Basin hydrothermal vent fields in the Gulf of California $(\%$ OC $=2-4)$, MV represents a system that is more typical of mid-ocean ridge hydrothermal vents worldwide $(\% \mathrm{OC}=0.3-$ 0.5; Wankel et al., 2012). Such environments could support the coupling of $\mathrm{C}_{1}-\mathrm{C}_{4}$ alkane degradation to SR in addition to alternative electron acceptors, such as metal oxides, particularly when the organic carbon load and associated SR rates are low (Wankel et al., 2012).

We studied the anaerobic oxidation of $\mathrm{C}_{1}-\mathrm{C}_{4}$ alkanes in metalliferous, organic-poor MV hydrothermal sediments across environmentally relevant temperature gradients. This biogeochemical investigation aimed to determine: (i) the temperature range over which hydrothermal sediment communities oxidize $\mathrm{C}_{1}-\mathrm{C}_{4}$ alkanes, (ii) the degree to which the anaerobic oxidation of these alkanes is coupled to SR, and (iii) the putative microbial phylotypes mediating $\mathrm{C}_{1}-\mathrm{C}_{4}$ alkane oxidation. To address these aims, a series of incubations were conducted using slurries of sediments collected from the MV system. These anaerobic batch reactors enabled the quantification and direct comparison of $\mathrm{C}_{1}-\mathrm{C}_{4}$ alkane oxidation and $\mathrm{SR}$ rates in a closed system across a broad range of discrete temperatures $\left(25,55\right.$, and $\left.75^{\circ} \mathrm{C}\right)$. Archaeal and bacterial community dynamics were investigated via pyrotaq sequencing in select batch reactor sediments that exhibited the greatest alkane oxidation activity over the incubation time course. The overall objective of this study was to advance our understanding of the nature and extent of the anaerobic oxidation of short-chain alkanes in hydrothermal systems and to ascertain the potential influence of these processes on other biogeochemical cycles. The data presented herein shed light on the relative contribution of the anaerobic oxidation of $\mathrm{C}_{2}-\mathrm{C}_{4}$ alkanes at different temperature regimes, the potential influence on AOM and the sulfur cycle, and the phylotypes most likely allied to the observed metabolisms.

\section{MATERIALS AND METHODS STUDY SITE AND SAMPLE COLLECTION}

Sediments were collected during an expedition with the DSV Alvin and $R / V$ Atlantis in July 2010 from the Chowder Hill hydrothermal vent field in MV ( $\left.48^{\circ} 27.44 \mathrm{~N}, 128^{\circ} 42.51 \mathrm{~W}\right)$ at $2413 \mathrm{~m}$ depth. Intact sediment cores were recovered with polyvinylchloride core sleeves (20-30 cm height, $6.35 \mathrm{~cm}$ ID, $0.32 \mathrm{~cm}$ sleeve thickness). Sediment sampling sites were selected based on in situ temperature depth profiles collected with DSV Alvin, the presence of chemoautotrophic microbial mats atop the sediments, and shimmering water from the diffuse flow sediments. At all sites, sediment temperature profiles were collected using the RTD probe, while dissolved alkanes and other gases were quantified using an in situ mass spectrometer (or ISMS; data not shown; Wankel et al., 2011). Pushcores were collected from areas where sediments temperatures ranged from $5-55^{\circ} \mathrm{C}$ in the upper $15 \mathrm{~cm}$ and $57-75^{\circ} \mathrm{C}$ at $30 \mathrm{~cm}$ sediment depth. Upon retrieval, cores were sealed and refrigerated for transport to the laboratory. Upon return to the lab, the overlying water in the sediment cores was replaced weekly with fresh, filter-sterilized anoxic seawater prior to initiation of the experiments.

\section{ANAEROBIC BATCH REACTORS WITH $\mathrm{C}_{1}-\mathrm{C}_{4}$ ALKANES}

In an anaerobic chamber (Coy Laboratory Products), $50 \mathrm{ml}$ of homogenized whole core sediment and $50 \mathrm{ml}$ of sterile, anaerobic artificial "diffuse vent fluid" were aliquoted into $200 \mathrm{ml}$ glass autoclaved serum vials for each treatment. The artificial vent fluid was modified from Widdel and Bak (1992) to include $1 \mathrm{mM}$ $\mathrm{Na}_{2} \mathrm{~S}$ to ensure that sediments remained at reducing conditions, $50 \mathrm{mM} \mathrm{Na} \mathrm{SO}_{4}^{2-}$ to reduce the possibility of sulfate limitation, and the $\mathrm{pH}$ adjusted to 6 to mimic the diffuse vent fluids. For each incubation temperature, the headspace was pressurized to slightly above 1 atm with the respective alkane $\left(\mathrm{C}_{1}-\mathrm{C}_{4}\right)$ or nitrogen $\left(\mathrm{N}_{2}\right)$ gas in duplicate batch reactors to avoid alkane limitation in the aqueous phase during the incubation time series. The reactors were incubated at temperatures reflecting the sea water-sediment interface $\left(25^{\circ} \mathrm{C}\right)$, the mid-depth average temperature $\left(55^{\circ} \mathrm{C}\right)$, and the highest temperatures measured at the deepest depth 
$\left(75^{\circ} \mathrm{C}\right)$. Flasks were shaken daily to ensure homogeneity in the slurry.

\section{GEOCHEMICAL MEASUREMENTS}

Concentrations of the dissolved $\mathrm{C}_{1}, \mathrm{C}_{2}, \mathrm{C}_{3}$, and $\mathrm{C}_{4}$ alkanes were determined after allowing the incubations to reach room temperature and by vigorously shaking samples to transfer gas from the anaerobic seawater media to the batch reactor headspace. Then, a $0.5 \mathrm{ml}$ sample of the headspace was injected into a gas chromatograph equipped with a flame ionization detector (Hewlett Packard 5890 Series II) and a packed column (RestekRt-XL) to quantify all alkanes. Injections of chemically pure alkanes (Airgas East, >99\% purity) were used to generate standard curves.

Sulfate reduction rates were determined by quantifying changes in sulfate and sulfide concentrations via ion chromatography and colorimetric assays, respectively (Cline, 1969; Joye et al., 2004). After shaking and allowing the sediment to settle, a $1 \mathrm{ml}$ fluid sub-sample was collected with a syringe from each reactor, filtersterilized $(0.2 \mu \mathrm{m})$ and transferred into a vial, preserved with $10 \mu \mathrm{HNO}_{3}$, and stored at $7^{\circ} \mathrm{C}$ until analysis. Concentrations of sulfate were determined using a Dionex ion chromatography system (Dionex Corp. Sunnyvale, CA, USA) at the University of Georgia, and $\mathrm{NaBr}$, a conservation tracer in the batch reactors, was measured simultaneously. A $1 \mathrm{ml}$ headspace sub-sample was collected and mixed with an equal volume of $20 \%$ zinc acetate to quantify gaseous $\mathrm{H}_{2} \mathrm{~S}$. Concentrations of $\mathrm{H}_{2} \mathrm{~S}$ were then determined colorimetrically as per Cline (1969). The reported values were corrected for $\mathrm{HS}^{-}$dissolved in the aqueous phase and reflect both sulfide species in the serum vial headspace and sediment slurry.

\section{DNA EXTRACTION, MASSIVELY PARALLEL SEOUENCING, AND PHYLOGENETIC ANALYSIS}

At the conclusion of each incubation, sediments were sub-sampled in an anaerobic chamber, and $\sim 15$ g of sediment slurry from each batch reactor was transferred directly into a $15 \mathrm{ml}$ cryovial, flash frozen in liquid nitrogen and stored at $-80^{\circ} \mathrm{C}$ until further molecular analyses. A time zero $\mathrm{T}_{0}$ sub-sample was collected at the start of the incubations to represent the initial community after homogenization, but prior to inoculation of the batch reactors. Total genomic DNA was extracted using phenol-chloroform (Barns et al., 1994; Dojka et al., 1998; Elshahed et al., 2004) modified to prevent nucleic acid loss and eliminate potential inhibitors of downstream PCR (as described in Webster et al. (2003)). Briefly, $0.5 \mathrm{~g}$ of sediment per batch reactor was washed with $5 \% \mathrm{HCl}$ and then DNA was extracted with addition of $200 \mu \mathrm{g}$ of poly adenylic acid (poly A) during the lysis step followed by incubation with lysozyme and proteinase $\mathrm{K}$, multiple freeze-thaw cycles with 5\% SDS, addition of hot phenol, extraction with phenol-chloroform, and elution in $50 \mu \mathrm{l}$ TE buffer $(10 \mathrm{mM}$ Tris hydrochloride, $1 \mathrm{mM}$ EDTA, pH 8.0). The concentration of extracts was determined using the Quant-iT ${ }^{\mathrm{TM}}$ dsDNA high sensitivity Assay (Invitrogen, Carlsbad, CA, USA).

DNA extracted from the $55^{\circ} \mathrm{C}$ incubations, which represented the highest rates of activity, was subjected to massively parallel sequencing of the $16 \mathrm{~S}$ ribosomal RNA (rRNA) gene using the primer pairs $27 \mathrm{~F} / 519 \mathrm{R}$ and $340 \mathrm{~F} / 806 \mathrm{R}$ for the bacterial V1 - V3 and archaeal V3 - V4 regions, respectively (Dowd et al., 2008; Acosta-Martínez et al., 2010). All pyrosequence data were submitted to the NCBI Sequence Read Archive under accession number SRA066151. The resulting reads were checked for sequence quality, trimmed, filtered, and analyzed in the software MOTHUR (Version 1.28.0; Schloss et al., 2009). Sequences were first filtered by the presence of sequence ambiguities, long homopolymers, and quality scores. The PyroNoise algorithm was then implemented in MOTHUR (i.e., shhh.flows) to remove sequences likely generated by pyrosequencing error (Quince et al., 2009). After selection of unique sequences, chimeras were identified and removed using UCHIME (http://www.drive5.com/uchime/). The resulting archaeal and bacterial reads were then aligned to the SILVA SEED Bacterial and Archaeal databases, containing 14,956 and 2,297 sequences, respectively.

For sequence classification, bootstrap values were set to nodes that had $>80 \%$ support in a bootstrap analysis of 100 replicates, and operational taxonomic units (OTUs) were defined as sequences sharing 97\% nucleotide sequence identity for further community analyses. A phylogenetic tree of representative Deltaproteobacteria (50 unique sequences selected in Mothur, i.e., sub.sample) was then generated with FastTree 2.0.0 (Price et al., 2010) using minimum-evolution subtree-pruning-regrafting and maximum-likelihood nearest-neighbor interchanges. Local support values shown are based on the Shimodaira-Hasegawa (SH) test with 1,000 resamples. Only values $>80 \%$ are shown on the branches as black circles. The tree was rooted to the 16S rRNA sequence of Archaeoglobus profundus DSM 5631 (NR_074522).

\section{RESULTS}

\section{$\mathrm{C}_{1}-\mathrm{C}_{4}$ ALKANE OXIDATION AS A FUNCTION OF TEMPERATURE IN BATCH REACTORS}

Batch reactor incubations were conducted using $\mathrm{MV}$ sediment slurries with one alkane gas $\left(\mathrm{C}_{1}, \mathrm{C}_{2}, \mathrm{C}_{3}\right.$, or $\left.\mathrm{C}_{4}\right)$ as the sole exogenous hydrocarbon, and incubated in the laboratory at 25, 55, and $75^{\circ} \mathrm{C}$ to reflect the range of temperatures measured in situ. Temperature affected the time required to detect alkane consumption, the percent of available substrate consumed, and the absolute rates of the anaerobic oxidation of $\mathrm{C}_{1}-\mathrm{C}_{4}$. In batch reactors at $55^{\circ} \mathrm{C}$, alkane consumption, defined as $10 \%$ of pool consumption, was evident after 71 days of incubation (Figure 1, top). In contrast, alkane consumption was detectable in $25^{\circ} \mathrm{C}$ batch reactors after 105 days for $\mathrm{C}_{1}-\mathrm{C}_{4}$. In $75^{\circ} \mathrm{C}$ batch reactors, substantial $\mathrm{C}_{2}-\mathrm{C}_{4}$ consumption was apparent after 105 days; however, $\mathrm{C}_{1}$ consumption was evident after a much shorter time period (30 days) at $75^{\circ} \mathrm{C}$.

Examining the fraction of available alkane consumed during the entire experiment (169 days), the greatest total consumption of $\mathrm{C}_{1}-\mathrm{C}_{4}$ occurred in the $55^{\circ} \mathrm{C}$ batch reactors $(\sim 93,75,93$, and $77 \%$ of $\mathrm{C}_{1}, \mathrm{C}_{2}, \mathrm{C}_{3}$, and $\mathrm{C}_{4}$, respectively). In addition, $\mathrm{C}_{1}$ was nearly depleted in the $75^{\circ} \mathrm{C}$ batch reactors by the end of the time series (with $>90 \%$ substrate consumed). With the exception of $\mathrm{C}_{1}$ at $75^{\circ} \mathrm{C}$, less than half of the available short-chain alkane pool was consumed during the incubation time course in 25 and $75^{\circ} \mathrm{C}$ batch reactors $\left(32,44,37\right.$, and $46 \%$ of $C_{1}, C_{2}, C_{3}$, and $C_{4}$ at 

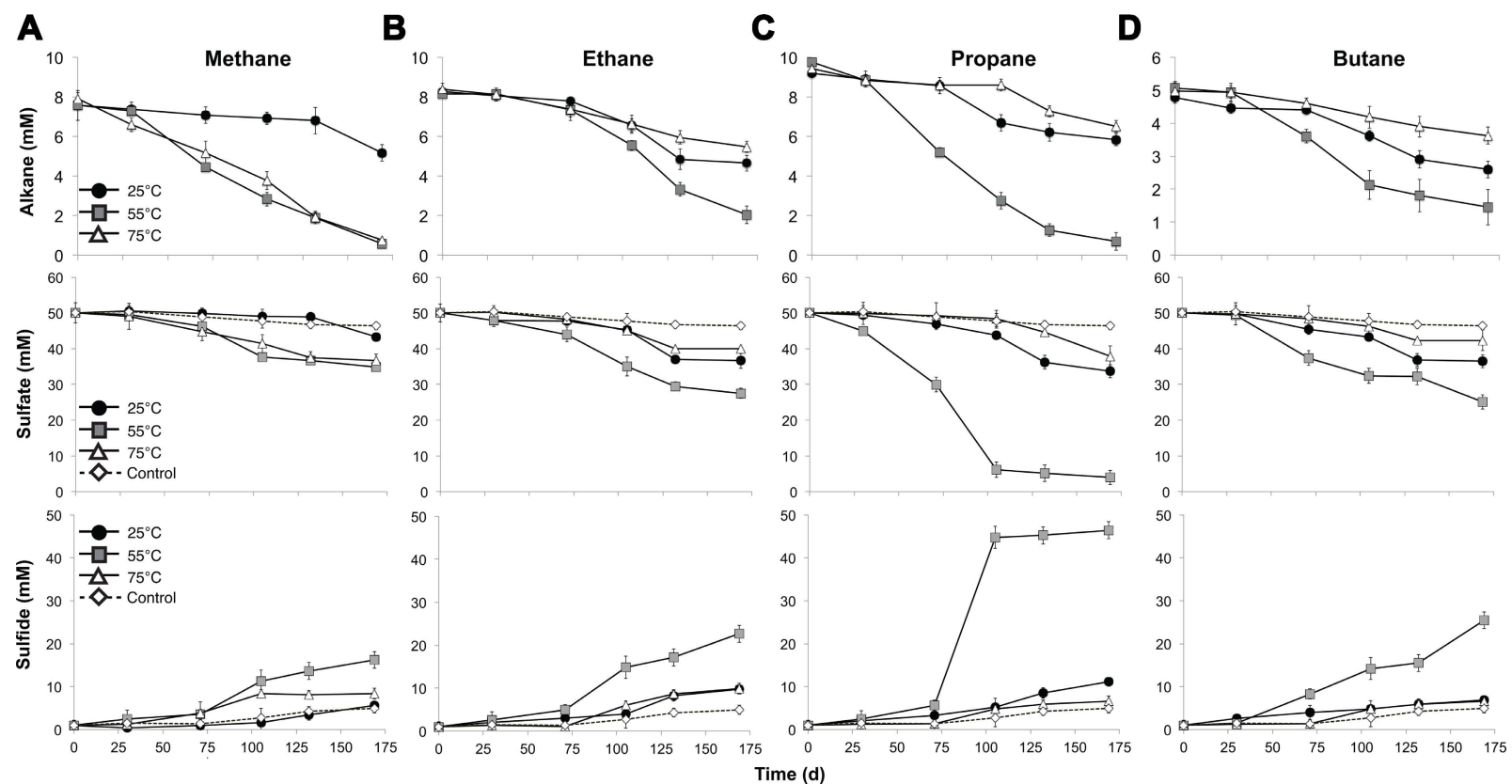

FIGURE 1 |Time course of the anaerobic oxidation of short-chain alkanes (top), consumption of sulfate (middle), and production of sulfide (bottom) in anaerobic batch reactors of Middle Valley hydrothermal sediments incubated with methane (A), ethane (B), propane (C), and butane $(D)$ at three discrete temperatures $\left(25,55\right.$, and $\left.75^{\circ} \mathrm{C}\right)$. Each time

$25^{\circ} \mathrm{C}$, respectively, and 35,31 , and $27 \%$ of $\mathrm{C}_{2}, \mathrm{C}_{3}$, and $\mathrm{C}_{4}$ at $75^{\circ} \mathrm{C}$, respectively).

Absolute rate measurements of the batch reactor sediments revealed that maximum $\mathrm{C}_{1}-\mathrm{C}_{4}$ oxidation occurred at $55^{\circ} \mathrm{C}$ $\left(\sim 42,36,54\right.$, and $23 \mathrm{nmol} \mathrm{cm}{ }^{-3}$ day $^{-1}$ for $C_{1}, C_{2}, C_{3}$, and $C_{4}$, respectively, $n=2$; Table 1$)$. Substantially lower rates of the anaerobic oxidation of $\mathrm{C}_{2}-\mathrm{C}_{4}$ were observed in all 25 and $75^{\circ} \mathrm{C}$ batch reactors $\left(\sim 21,16\right.$, and $8 \mathrm{nmolcm}^{-3} \mathrm{day}^{-1}$ for $\mathrm{C}_{2}, \mathrm{C}_{3}$, and $\mathrm{C}_{4}$ at $25^{\circ} \mathrm{C}$, respectively, $n=2$, and $\sim 17,17$, and $8 \mathrm{nmolcm}^{-3}$ day $^{-1}$ for $\mathrm{C}_{2}, \mathrm{C}_{3}$, and $\mathrm{C}_{4}$ at $75^{\circ} \mathrm{C}$, respectively, $n=2$ ). In contrast to the other short-chain alkanes, maximal rates of AOM were also observed at $75^{\circ} \mathrm{C}\left(\sim 42 \mathrm{nmolcm}^{-3} \mathrm{day}^{-1}, n=2\right)$, while rates decreased to less than half of these AOM maxima at $25^{\circ} \mathrm{C}\left(14 \mathrm{nmolcm}^{-3} \mathrm{day}^{-1}\right.$, $n=2)$.

\section{SULFATE REDUCTION COUPLED TO $\mathrm{C}_{1}-\mathrm{C}_{4}$ ALKANE OXIDATION ACROSS TEMPERATURE REGIMES}

In addition to a dependence on short-chain alkane length, temperature constrained SR in the anaerobic batch reactors, influencing quantified changes in porewater sulfate and total sulfide. Decreases in sulfate concentration were observed in all batch reactors across time and temperature regimes, consistent with trends for the anaerobic oxidation of $\mathrm{C}_{1}-\mathrm{C}_{4}$ alkanes. Analogous to alkane consumption dynamics, sulfate consumption was appreciable (defined as $>10 \%$ substrate consumption) after 71 days of incubation in $\mathrm{C}_{1}-\mathrm{C}_{4}$ batch reactors at $55^{\circ} \mathrm{C}$ (Figure 1 , middle). In contrast, there was a lag of $\sim 105$ days in $C_{2}, C_{3}$, and $C_{4}$ batch reactors prior to substantial sulfate consumption at both the lowest $\left(25^{\circ} \mathrm{C}\right)$ and highest $\left(75^{\circ} \mathrm{C}\right)$ incubation temperature. Over the span point represents the average of duplicate reactors with bars indicating the data range. For sulfate and sulfide measurements, the control in each panel represents the average sulfate consumption and sulfide production in the batch reactors with nitrogen for each incubation temperature as described in the text.
Table 1 | Volume-specific rate measurements of the anaerobic oxidation of methane, ethane, propane, and butane and sulfate reduction in batch reactors incubated at 25,55 , and $75^{\circ} \mathrm{C}$.

\begin{tabular}{|c|c|c|}
\hline & $\begin{array}{l}\text { Anaerobic oxidation } \\
\mathrm{nmol} \mathrm{cm}^{-3} \text { day }^{-1}\end{array}$ & $\begin{array}{l}\text { Sulfate reduction } \\
\mathrm{nmol} \mathrm{cm}^{-3} \text { day }^{-1}\end{array}$ \\
\hline Methane $-25^{\circ} \mathrm{C}$ & $14.33 \pm 2.88$ & $15.01 \pm 2.31$ \\
\hline Methane $-55^{\circ} \mathrm{C}$ & $41.45 \pm 1.17$ & $55.83 \pm 4.91$ \\
\hline Methane $-75^{\circ} \mathrm{C}$ & $42.22 \pm 1.91$ & $68.03 \pm 5.01$ \\
\hline Ethane $-25^{\circ} \mathrm{C}$ & $21.39 \pm 4.77$ & $53.61 \pm 6.53$ \\
\hline Ethane $-55^{\circ} \mathrm{C}$ & $36.03 \pm 4.46$ & $99.30 \pm 8.48$ \\
\hline Ethane $-75^{\circ} \mathrm{C}$ & $17.22 \pm 3.59$ & $47.94 \pm 3.65$ \\
\hline Propane $-25^{\circ} \mathrm{C}$ & $19.93 \pm 2.81$ & $71.96 \pm 7.25$ \\
\hline Propane $-55^{\circ} \mathrm{C}$ & $53.66 \pm 2.52$ & $238.36 \pm 10.77$ \\
\hline Propane $-75^{\circ} \mathrm{C}$ & $17.26 \pm 1.26$ & $60.37 \pm 6.18$ \\
\hline Butane $-25^{\circ} \mathrm{C}$ & $12.84 \pm 2.81$ & $55.27 \pm 8.68$ \\
\hline Butane $-55^{\circ} \mathrm{C}$ & $23.07 \pm 5.13$ & $113.46 \pm 15.37$ \\
\hline Butane $-75^{\circ} \mathrm{C}$ & $8.01 \pm 1.13$ & $34.22 \pm 2.39$ \\
\hline
\end{tabular}

Rates were determined from the consumption of alkanes and sulfate over the incubation time course. Each point represents the average of duplicate reactors with the standard error. To account for background sulfate reduction (due to autochthonous carbon, etc.), the rates measured in the alkane treatments have been corrected via subtraction of those measured in the control (nitrogen) batch reactors. 
of the incubation time series (169 days), the greatest reduction in sulfate concentration was at $55^{\circ} \mathrm{C}(\sim 30,45,92$, and $49 \%$ of total sulfate consumed in the $\mathrm{C}_{1}, \mathrm{C}_{2}, \mathrm{C}_{3}$, and $\mathrm{C}_{4}$ reactors, respectively). Sulfate consumption was also observed in the $\mathrm{N}_{2}$-control batch reactors, albeit to a much smaller extent $(\sim 8,11$, and $2 \%$ at 25,55 , and $75^{\circ} \mathrm{C}$, respectively). SR was also assessed by quantifying the production of gaseous and dissolved sulfide in the batch incubations (Figure 1, bottom). In all reactors, sulfide concentrations at the end of each incubation time period accounted for greater than $90 \%$ of the initial total sulfate plus sulfide concentration; therefore, these mass balance estimates were within $10 \%$ of the total sulfur species observed initially.

Concomitant with the anaerobic oxidation of $\mathrm{C}_{2}-\mathrm{C}_{4}$ rates, maximum SR rates were observed at $55^{\circ} \mathrm{C}$ for the nonmethane short-chain alkanes $\left(\sim 99,238\right.$, and $113 \mathrm{nmolcm}^{-3} \mathrm{day}^{-1}$ for $\mathrm{C}_{2}, \mathrm{C}_{3}$, and $\mathrm{C}_{4}$, respectively, $n=2$ ) (Table 1). However, maximum SR rates associated with AOM occurred at $75^{\circ} \mathrm{C}\left(\sim 68 \mathrm{nmolcm}^{-3} \mathrm{day}^{-1}\right)$, with lower rates at $55^{\circ} \mathrm{C}$ $\left(\sim 55 \mathrm{nmolcm}^{-3} \mathrm{day}^{-1}, n=2\right)$ and even more modest rates at $25^{\circ} \mathrm{C}\left(\sim 15 \mathrm{nmolcm}^{-3} \mathrm{day}^{-1}, n=2\right)$. In comparison to maximal SR rates at $55^{\circ} \mathrm{C}$, SR rates linked to $\mathrm{C}_{2}-\mathrm{C}_{4}$ oxidation were lower at both 25 and $75^{\circ} \mathrm{C}\left(\sim 54,72\right.$, and $55 \mathrm{nmolcm}^{-3}$ day $^{-1}$ for $\mathrm{C}_{2}, \mathrm{C}_{3}$, and $\mathrm{C}_{4}$ at $25^{\circ} \mathrm{C}$, respectively, $n=2$, and $\sim 48,60$, and 34 nmolcm $^{-3} \mathrm{day}^{-1}$ for $\mathrm{C}_{2}, \mathrm{C}_{3}$, and $\mathrm{C}_{4}$ at $75^{\circ} \mathrm{C}$, respectively, $n=2)$.

The observed ratio $(\mathrm{mol} / \mathrm{mol})$ of $\mathrm{C}_{1}-\mathrm{C}_{4}$ oxidation to $\mathrm{SR}$ in the batch reactors was then compared to the predicted stoichiometric ratio assuming the sulfate-dependent complete oxidation of $\mathrm{C}_{1}-\mathrm{C}_{4}$ alkanes to $\mathrm{CO}_{2}$ (from Kniemeyer et al., 2007). These ratios are corrected for the consumption of sulfate in the control $\left(\mathrm{N}_{2}\right)$ batch reactors as an estimate for SR linked to non-alkane organic carbon donors present in the sediment. The ratio of mol alkane consumed per mol sulfate reduced was $1.42,1.11$, and $0.93 \mathrm{mmol} \mathrm{C}_{1} \mathrm{mmol}^{-1}$ sulfate; $0.59,0.54$, and $0.54 \mathrm{mmol}$ of $\mathrm{C}_{2}$ $\mathrm{mmol}^{-1}$ sulfate; $0.42,0.34$, and $0.43 \mathrm{mmol}$ of $\mathrm{C}_{3} \mathrm{mmol}^{-1}$ sulfate; and $0.35,0.31$, and $0.35 \mathrm{mmol}$ of $\mathrm{C}_{4} \mathrm{mmol}^{-1}$ sulfate at 25, 55, and $75^{\circ} \mathrm{C}$, respectively (Table 2 ). These ratios closely mirror the predicted stoichiometric ratios of $1,0.5,0.4$, and 0.3 for $\mathrm{C}_{1}-\mathrm{C}_{4}$, respectively.

\section{PHYLOGENETIC DIVERSITY AND DISTRIBUTION IN SEDIMENTS FROM BATCH $\mathrm{C}_{1}-\mathrm{C}_{4}$ REACTORS}

After sequence processing and denoising as previously described, a total of $5783,6562,5307,6985$, and 8796 bacterial sequences were analyzed from sediments incubated with $\mathrm{N}_{2}, \mathrm{C}_{1}, \mathrm{C}_{2}, \mathrm{C}_{3}$, and $\mathrm{C}_{4}$ alkane, respectively, and 7965 bacterial sequences from the $\mathrm{T}_{0}$ sediment. There were substantial shifts at the phyla level between the communities incubated with different alkane substrates in comparison to the control batch reactor and $\mathrm{T}_{0}$ sediment community (Figure 2). From the initial sediment community, sequences allied to the Bacteroidetes and Fusobacteria decreased from $\sim 9$ and $40 \%$ of $\mathrm{T}_{0}$ sequences respectively, to less than $0.5 \%$ of sequences in all batch reactor libraries. In turn, sequences allied to the Proteobacteria, Firmicutes, Candidate Division OP8, Chloroflexi, and Actinobacteria increased in batch reactor libraries compared to $\mathrm{T}_{0}$ sequences. Notably, the Proteobacteria, which comprised $\sim 36 \%$ of $\mathrm{T}_{0}$ sequences, increased in representation in the $\mathrm{N}_{2}, \mathrm{C}_{1}, \mathrm{C}_{2}$, and
Table 2 | The predicted and calculated stoichiometric ratios for the anaerobic oxidation of methane, ethane, propane, and butane coupled to the reduction of sulfate to sulfide.

\begin{tabular}{lll}
\hline & $\begin{array}{l}\text { Stoichiometric } \\
\text { Ratio } \mathbf{( m o l} / \mathbf{m o l})\end{array}$ & $\begin{array}{l}\text { Observed Ratio } \\
\text { ( } \mathbf{m o l} / \mathbf{m o l})\end{array}$ \\
\hline Methane $-25^{\circ} \mathrm{C}$ & 1 & 1.42 \\
Methane $-55^{\circ} \mathrm{C}$ & 1 & 1.11 \\
Methane $-75^{\circ} \mathrm{C}$ & 1 & 0.93 \\
Ethane $-25^{\circ} \mathrm{C}$ & 0.5 & 0.59 \\
Ethane $-55^{\circ} \mathrm{C}$ & 0.5 & 0.54 \\
Ethane $-75^{\circ} \mathrm{C}$ & 0.5 & 0.54 \\
Propane $-25^{\circ} \mathrm{C}$ & 0.4 & 0.42 \\
Propane $-55^{\circ} \mathrm{C}$ & 0.4 & 0.34 \\
Propane $-75^{\circ} \mathrm{C}$ & 0.4 & 0.43 \\
Butane $-25^{\circ} \mathrm{C}$ & 0.31 & 0.35 \\
Butane $-55^{\circ} \mathrm{C}$ & 0.31 & 0.31 \\
Butane $-75^{\circ} \mathrm{C}$ & 0.31 & 0.35 \\
\hline
\end{tabular}

From closed system batch reactors, the mol alkane lost was calculated per mol sulfate reduced at 25,55 , and $75^{\circ} \mathrm{C}$, respectively. To account for background sulfate reduction (due to autochthonous carbon, etc.), ratios have been corrected via subtraction of those measured in the control (nitrogen) batch reactors.

$\mathrm{C}_{3}$ sequence libraries ( $\sim 49,58,41$, and $46 \%$, respectively). The Firmicutes also increased substantially from the $\mathrm{T}_{0}$ composition $(\sim 4 \%)$ in $\mathrm{N}_{2}, \mathrm{C}_{2}, \mathrm{C}_{3}$, and $\mathrm{C}_{4}$ sequences $(\sim 11,12,12$, and $59 \%$, respectively).

Among the Proteobacterial sequences allied to known sulfatereducing Deltaproteobacteria, there was a substantial increase from $\mathrm{T}_{0}$ sequences $(\sim 15 \%)$ in the $\mathrm{N}_{2}, \mathrm{C}_{1}, \mathrm{C}_{2}, \mathrm{C}_{3}$, and $\mathrm{C}_{4}$ sequence libraries $(\sim 39,87,70,88$, and $86 \%$, respectively). Concurrently, there was a substantial decrease in the representation of Epsilonproteobacteria in the $\mathrm{N}_{2}, \mathrm{C}_{1}, \mathrm{C}_{2}, \mathrm{C}_{3}$, and $\mathrm{C}_{4}$ sequence libraries ( $239,3,17,7$, and $9 \%$, respectively). Within the putative sulfate-reducing phylotypes, the $\mathrm{C}_{1}$ library was comprised primarily (>92\%) of sequences allied to Desulfobulbus, as shown in a previous study of MV sediment communities associated with AOM (Wankel et al., 2012). Analysis of 16S rRNA gene libraries revealed that a distinct lineage of SRB are the predominant Deltaproteobacterial phylotypes in the $\mathrm{C}_{2}-\mathrm{C}_{4}$ reactor communities, comprising $\sim 93,91$, and $95 \%$ of $\mathrm{C}_{2}, \mathrm{C}_{3}$, and $\mathrm{C}_{4}$ sequences, respectively (Figure 4). The most closely related phylotypes (93-99\% nucleotide sequence identity) were previously recovered in two $16 \mathrm{~S}$ rRNA-based surveys of sulfate-reducing anaerobic enrichments of Guaymas Basin sediments with $\mathrm{C}_{4}$ at $60^{\circ} \mathrm{C}$ (Butane60-GuB, accession no. EF077228) and with $\mathrm{C}_{1}$ at $37^{\circ} \mathrm{C}$ (Guaymas_Bac9 clone, accession no. FR682643; Kniemeyer et al., 2007; Kellermann et al., 2012).

A total of 1290, 1724, 1540, 1916, 1780, and 2846 Euryarchaeotal sequences were further analyzed from the $\mathrm{N}_{2}, \mathrm{C}_{1}$, $\mathrm{C}_{2}, \mathrm{C}_{3}$, and $\mathrm{C}_{4}$ batch reactors and $\mathrm{T}_{0}$ sediments, respectively (Figure 3). There were notable shifts in the sequences allied to 


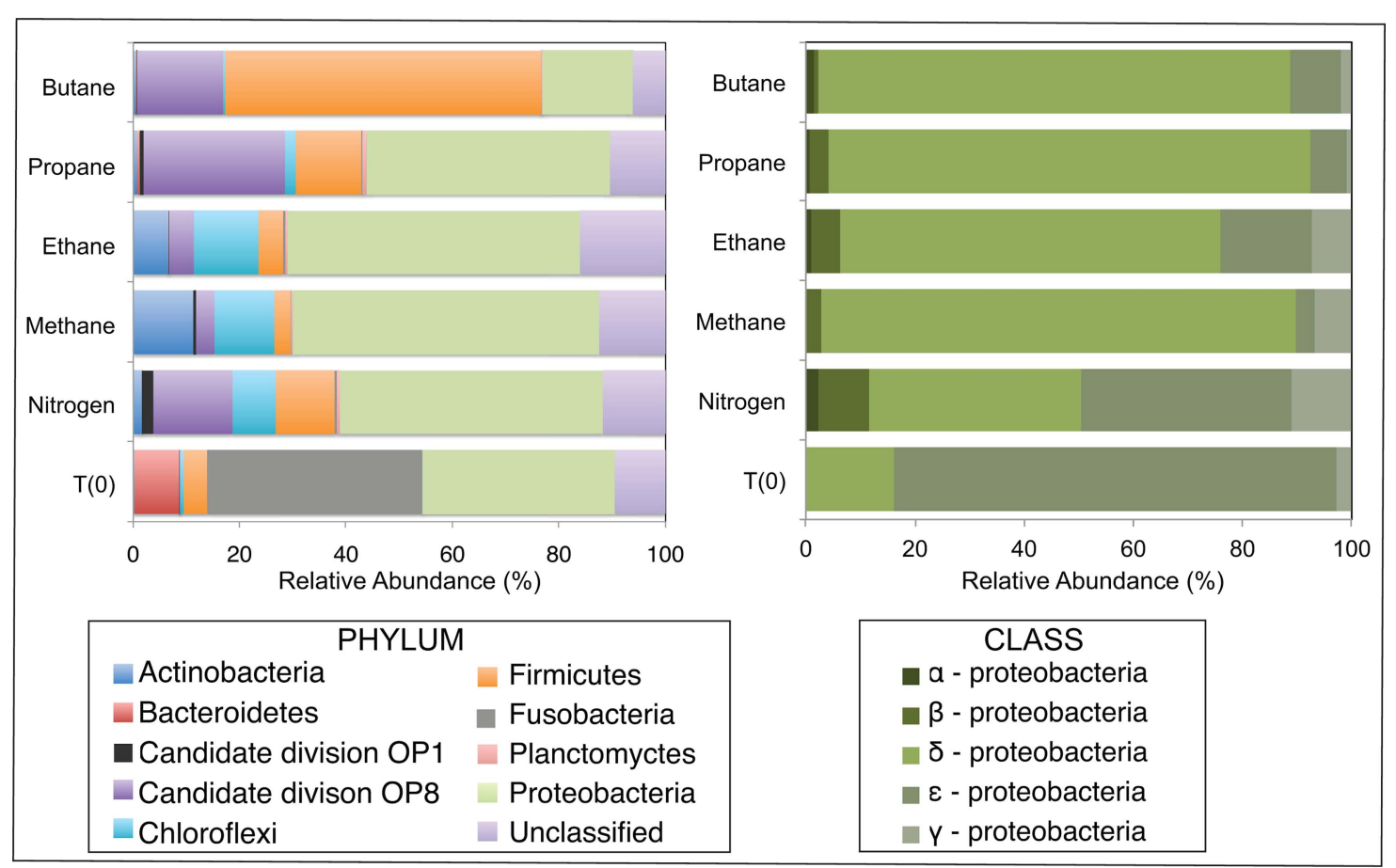

FIGURE 2 | Relative abundance (percentage) of bacteria determined from massively parallel sequencing of DNA recovered from anaerobic batch reactor sediments incubated with methane, ethane, propane, butane, and nitrogen at $55^{\circ} \mathrm{C}$ and pre-incubation $\left(\mathrm{T}_{0}\right)$ sediments. Left and right side panels show the taxonomic breakdown of sequences at the phylum and class level, respectively. Legend indicates operational taxonomic units (OTUs), defined as sequences sharing $97 \%$ nucleotide sequence identity.

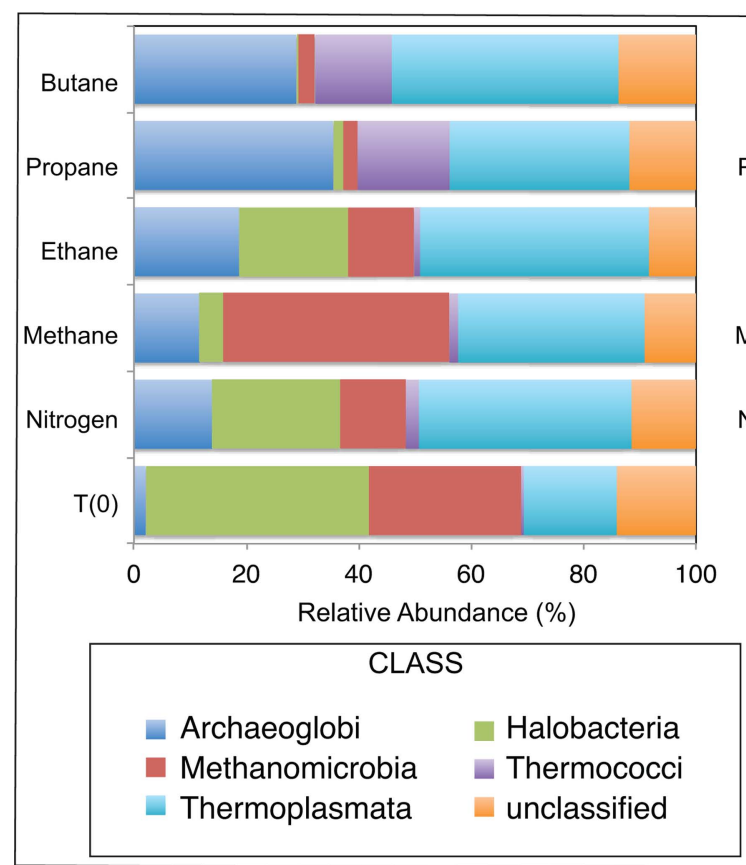

FIGURE 3 | Relative abundance (percentage) of archaea determined from massively parallel sequencing of DNA recovered from anaerobic batch reactor sediments incubated with methane, ethane, propane, butane, and nitrogen at $55^{\circ} \mathrm{C}$ and pre-incubation $\left(T_{0}\right)$ sediments.

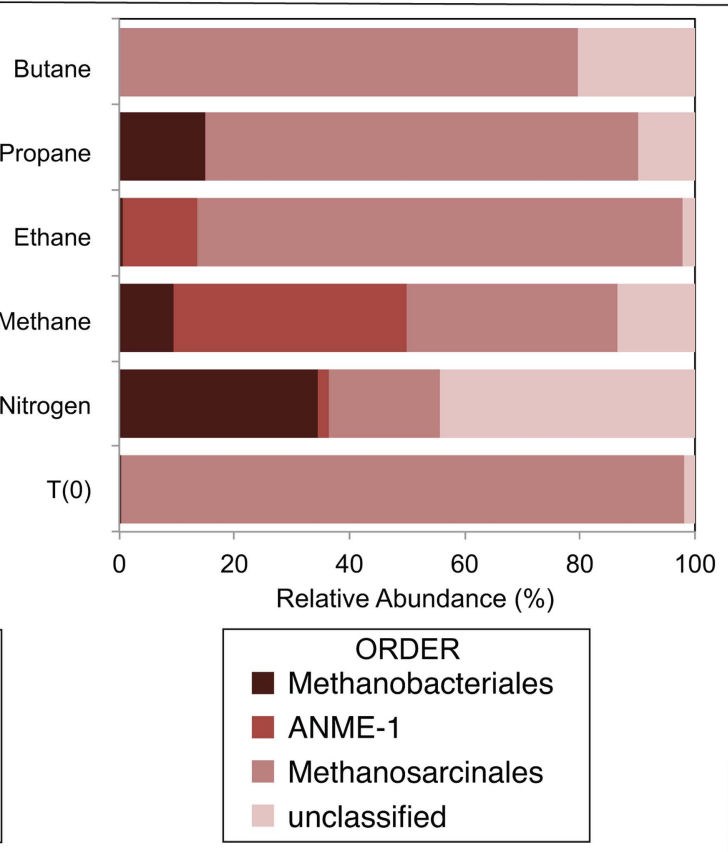

Left and right side panels show the taxonomic breakdown of sequences at the class and order level, respectively. Legend indicates operational taxonomic units (OTUs), defined as sequences sharing $97 \%$ nucleotide sequence identity. 
the predominant Euryarchaeotal phyla - Archaeoglobi, Halobacteria, Methanomicrobia, Thermococci, and Thermoplasmata - from the initial sediment community and across the different alkane batch incubations. Over $40 \%$ of sequences were allied to the Halobacteria in $\mathrm{T}_{0}$ sediments, decreasing to comprise $<0.5-29 \%$ of batch reactor sequences. In contrast, Archaeoglobi sequences increased from $\sim 2 \%$ of $\mathrm{T}_{0}$ sequences to $\sim 14,12,19,36$, and $29 \%$ of $\mathrm{N}_{2}, \mathrm{C}_{1}, \mathrm{C}_{2}, \mathrm{C}_{3}$, and $\mathrm{C}_{4}$ sequences, respectively. Other trends in Euryarchaeotal community structure included an increase in Methanomicrobia from $27 \%$ of $\mathrm{T}_{0}$ sequences to $40 \%$ of $\mathrm{C}_{1}$ sequences.

Within the Methanomicrobia, there were also substantial changes in sequences allied to known methanogens and methaneoxidizing phylotypes. Methanosarcinales comprised $>97 \%$ of $\mathrm{T}_{0}$ sequences and $\sim 19,36,84,75$, and $80 \%$ of $\mathrm{N}_{2}, \mathrm{C}_{1}, \mathrm{C}_{2}, \mathrm{C}_{3}$, and $\mathrm{C}_{4}$ sequences, respectively. In contrast, Methanobacteriales increased from $<0.5 \%$ of $\mathrm{T}_{0}$ sequences to $\sim 35,9$, and $26 \%$ of $\mathrm{N}_{2}$, $\mathrm{C}_{1}$, and $\mathrm{C}_{3}$ sequences (there was no substantial increase in $\mathrm{C}_{2}$ or $\mathrm{C}_{4}$ sequences). For the putative methane-oxidizing communities, over 40 and $12 \%$ of $C_{1}$ and $C_{2}$ sequences were allied to ANME-1 ribotypes.

\section{DISCUSSION}

The microbial degradation of short-chain alkanes under oxic conditions and the anaerobic oxidation of methane and other heavier hydrocarbons have been extensively studied in diverse terrestrial and marine environments. Despite studies indicating short-chain alkane degradation in anoxic deep sea sediments (Sassen et al., 2004; Mastalerz et al., 2009; Quistad and Valentine, 2011) and the abundance of short-chain alkanes in hydrocarbon-rich ecosystems (Milkov, 2005; Cruse and Seewald, 2006), relatively little is known about the biogeochemical importance of these processes or the diversity of anaerobic short-chain alkane degrading microorganisms in marine hydrothermal sediments. The data here provide a deeper glimpse into the anaerobic oxidation of $\mathrm{C}_{2}-\mathrm{C}_{4}$ in metalliferous hydrothermal sediments and reveal that rates of the anaerobic oxidation of $\mathrm{C}_{2}-\mathrm{C}_{4}$ alkanes in hydrothermal vent sediment are heavily influenced by temperature and coupled to SR, though the rates presented herein are derived from conditions not likely to be present in situ, and as such care should be taken when extrapolating these rates to natural processes. In batch reactor sediments that exhibited the most substantial activity, changes in the representation of phylotypes in libraries generated via high throughput sequencing implicate Deltaproteobacteria in $\mathrm{C}_{2}-\mathrm{C}_{4}$ alkane degradation, and shifts in microbial community composition indicate that other members of the community respond to the presence of short-chain alkanes (though the mechanisms underlying this response remain unknown).

These data revealed a preferential consumption of $\mathrm{C}_{2}-\mathrm{C}_{4}$ at $55^{\circ} \mathrm{C}$, suggesting that the active alkane degraders in these hydrothermal vent sediments are thermophilic. Furthermore, these ex situ calculated rates for the anaerobic oxidation of $\mathrm{C}_{2}-$ $\mathrm{C}_{4}$ were in the same range $\left(\mathrm{nmolcm}^{-3} \mathrm{day}^{-1}\right)$ as the recently reported anaerobic oxidation of $\mathrm{C}_{3}$ in marine hydrocarbon seep sediments and as AOM rates measured in organic-rich coastal sediments at the sulfate-methane transition zone (Alperin et al., 1988; Hoehler et al., 1994; Girguis et al., 2003; Wegener et al., 2008;
Quistad and Valentine, 2011). Based on lag time and total alkane degraded over time, $\mathrm{C}_{3}$ appeared to be the preferred substrate in the $55^{\circ} \mathrm{C}$ incubations, followed by $\mathrm{C}_{1}, \mathrm{C}_{4}$, and $\mathrm{C}_{2}$, respectively. Similar trends in the biodegradation of short-chain alkanes have been found in stable isotopic studies of hydrocarbon reservoirs at temperatures below $60^{\circ} \mathrm{C}$ with a preference for $\mathrm{C}_{3}$ followed by $\mathrm{C}_{4}$ and then $\mathrm{C}_{2}$ (Boreham et al., 2001; Wenger et al., 2002; Larter et al., 2005).

Various physicochemical and biotic parameters may impact the degree of $\mathrm{C}_{2}-\mathrm{C}_{4}$ consumption in ex situ studies and in the natural environment. Notably, the gaseous alkanes were maintained at above saturation conditions for the liquid phase of the batch incubations until the end of the time series to ensure substrate availability (dissolved concentrations of $\sim 1.42,1.89,0.91$, and $1.05 \mathrm{mM}$ for $\mathrm{C}_{1}, \mathrm{C}_{2}, \mathrm{C}_{3}$, and $\mathrm{C}_{4}$, respectively). Under elevated hydrostatic pressure in the deep sea, hydrothermal vent fluids at $\mathrm{MV}$ reach $\mathrm{C}_{1}$ concentrations of $\sim 20 \mathrm{mM}$, while the other short-chain alkanes are an order of magnitude lower $(\sim 220,55$, and $6 \mu \mathrm{M}$ for $\mathrm{C}_{2}, \mathrm{C}_{3}$, and $\mathrm{C}_{4}$, respectively; Cruse and Seewald, 2006). Although $C_{1}$ is most likely more abundant than $C_{3}$ in $M V$ hydrothermal sediments, the in situ rates of $\mathrm{C}_{3}$ degradation may be appreciable due to the inherent reactivity of secondary $\mathrm{C}-\mathrm{H}$ bonds (Schink and Friedrich, 1994; Rabus et al., 2001; Van Hamme et al., 2003).

Our results also suggest that, at the highest incubation temperatures, $\mathrm{AOM}$ in $\mathrm{MV}$ sediments occurs at higher rates than the anaerobic oxidation of $\mathrm{C}_{2}-\mathrm{C}_{4}$ alkanes. In the higher temperature $\left(75^{\circ} \mathrm{C}\right)$ incubations, $\mathrm{C}_{1}$ consumption was evident after 30 days and reached near deplete concentrations (90\% substrate consumed), while there was a much longer lag period until $\mathrm{C}_{2}-\mathrm{C}_{4}$ degradation (105 days) and much less of the substrates were consumed by the completion of the time series (27-35\%; Figure 1, top). In contrast, a greater proportion of $\mathrm{C}_{2}$ and $\mathrm{C}_{4}$ (44 and $46 \%$, respectively) were consumed than $\mathrm{C}_{1}$ and $\mathrm{C}_{3}$ (32 and $37 \%$, respectively) in the lower temperature incubations $\left(25^{\circ} \mathrm{C}\right)$. The increased AOM activity at the higher end of the temperature range in MV sediments is consistent with our previous observations of AOM in these metalliferous sediments (Wankel et al., 2012), and is also consistent with the growth temperatures of archaeal communities (such as ANME phylotypes) from hydrothermal vents, which indicate that many archaea live at their maximum growth temperature in situ (Kimura et al., 2013). Another line of evidence for thermophilic AOM was also provided in a recent $16 \mathrm{~S}$ rRNA based-study identifying a putatively high temperature-adapted ANME subgroup in both hydrothermal sediments from Guaymas Basin and diffuse vent fluids from Axial Volcano and the Endeavor Segment of Juan de Fuca Ridge (Merkel et al., 2013).

Notably, the anaerobic oxidation of $\mathrm{C}_{1}-\mathrm{C}_{4}$ was coupled to SR across temperature gradients in $\mathrm{MV}$ sediment batch reactors. Sulfate loss $(\sim 2-6 \mathrm{mM})$ was also observed over the time series in alkane-free control batch reactors (Figure 1, middle). In comparison to SR linked to the oxidation of shortchain alkanes, this modest sulfate consumption relates to the oxidation of endogenous substrates, particularly organic carbon, by the sediment communities (Gieg etal., 1999). The sediment organic carbon pool of $\mathrm{MV}$ sediments $(\%$ OC $=\sim 0.5$ 
in this study) is low in comparison to the high amounts of organic matter that characterize other deep sea environments with known short-chain alkane degraders, such as the organic-rich Guaymas Basin hydrothermal sediments (Jorgensen et al., 1992; Kniemeyer et al., 2007). The observed SR rates in $\mathrm{C}_{1}-\mathrm{C}_{4}$ batch reactors of MV sediments demonstrate the potential for organic carbon-poor, high temperature mid-ocean ridge systems to support the anaerobic oxidation of short-chain alkanes coupled to SR.

Our results further indicate that short-chain alkane degradation linked to SR might considerably influence sulfate cycling at these sedimented hydrothermal vents. In accordance with the observed stoichiometries, SR coupled to the anaerobic oxidation of $\mathrm{C}_{2}, \mathrm{C}_{3}$, and $\mathrm{C}_{4}$ proceeded at a faster rate than $\mathrm{AOM}$ at mesophilic and thermophilic temperatures $\left(25\right.$ and $55^{\circ} \mathrm{C}$, respectively). However, the $\mathrm{SR}$ rates in anaerobic batch reactors were observed under sulfate-replete conditions, while the sulfate pool in situ depends on the downward advection of seawater and the activity of sulfide-oxidizing microbial communities (Bowles et al., 2011). Sulfate availability will become limiting at greater sediment depths from the seawater surface. Therefore, the $\mathrm{C}_{2}, \mathrm{C}_{3}$, and $\mathrm{C}_{4}$-degrading, sulfate-reducing microbial communities likely compete for available sulfate and might indirectly limit $\mathrm{AOM}$ in the temperature range from $\sim 25-55^{\circ} \mathrm{C}$. As previously discussed, the anaerobic oxidation of these aliphatic hydrocarbons coupled to the reduction of sulfate to sulfide yields greater energy per unit substrate than AOM. Such processes could constrain methane release from the deep-sea with a critical impact on the global carbon cycle and climate. Furthermore, if AOM activity peaks at greater sediment depths and higher temperatures in situ as predicted by rate measurements, then sulfate will most likely have been depleted in these sediment horizons. Sulfate limitation may thus result in the coupling of AOM to alternative electron acceptors (i.e., iron oxides), as indicated in previous studies of MV high temperature sediment incubations (Wankel et al., 2012).

Comparison of bacterial communities in batch reactor sediments with maximum rates of $\mathrm{C}_{1}-\mathrm{C}_{4}$ degradation, via massively parallel pyrosequencing, suggests that members of the sulfatereducing Deltaproteobacteria mediate the anaerobic oxidation of short-chain alkanes in MV hydrothermal vent sediments (Figure 2). As these sequence data are based on PCR amplification of 16S rRNA genes and are semi-quantitative, an order of magnitude difference in phyla should represent shifts in community composition. Within the Proteobacteria, there was a substantial increase of Deltaproteobacteria in $\mathrm{C}_{1}-\mathrm{C}_{4}$ sequences compared to the initial $\mathrm{T}_{0}$ bacterial composition dominated by Epsilonproteobacteria. Phylogenetic analyses revealed a novel subgroup of SRB that comprised $>90 \%$ of these Deltaproteobacteria in $\mathrm{C}_{2}-\mathrm{C}_{4}$ batch reactor sequences (Figure 4). This lineage of Deltaproteobacteria is most closely related to $\mathrm{C}_{4}$-degrading $\mathrm{SRB}$ from Guaymas Basin, and therefore, may be a thermophilic short-chain alkane degrader group (Kniemeyer et al., 2007). Intriguingly, the predominant phylum in $\mathrm{C}_{4}$ batch reactor sequences is the Firmicutes, which contains sulfate-reducing members of previous enrichments with $\mathrm{C}_{3}$ and $\mathrm{C}_{4}$ (Kniemeyer et al., 2007; Savage et al., 2010). However, the majority of Firmicutes sequences were most closely related (98-99\%) to uncultured Bacillus clones from hydrocarboncontaminated soils (Wang et al., 2011). The greater proportion of this uncharacterized Bacillus group in comparison to SRB may have also affected the lower rates of the anaerobic oxidation of $\mathrm{C}_{4}$ in comparison to $\mathrm{C}_{2}$ or $\mathrm{C}_{3}$ in batch incubations. Future studies should determine if this putative thermophilic short-chain alkane degrader group of SRB is widespread in other hydrothermally influenced environments.

Amongst the batch reactor sediment communities, shifts in archaeal phylogenetic composition were also revealed via $16 \mathrm{~S}$ rRNA pyrosequencing. There was a substantial increase of Methanomicrobia sequences in $\mathrm{C}_{1}$-incubated sediments compared to the initial community and $\mathrm{C}_{2}-\mathrm{C}_{4}$ batch reactor sediments, with an order of magnitude enrichment of ANME-1 phylotypes within the Methanomicrobia (Figure 3). The microbes known to catalyze AOM form three phylogenetically distinct Euryarchaeaota clusters (ANME-1, ANME-2, and ANME-3) that often appear to live in consortia with SRB (Hoehler et al., 1994; Boetius et al., 2000; Orphan etal., 2001). However, ANME-1 phylotypes are also found as single cells in sediments, and recent studies have shown that AOM can occur in the absence of SR and that some ANME are not directly dependent on SRB activity (Beal et al., 2009; Milucka et al., 2012; Wankel et al., 2012). There was also a notable increase in Archaeoglobus sequences in $\mathrm{C}_{1}-\mathrm{C}_{4}$ batch reactors from the initial community composition (Figure 3), which contain hyperthermophilic species known to mediate SR (Shen and Buick, 2004). Based on microbial isolates and enrichments from both deep sea and terrestrial ecosystems, no evidence to date indicates that non-methane short-chain alkanes are anaerobically oxidized by microbial consortia or sulfate-reducing archaea (Kniemeyer et al., 2007; Savage et al., 2010; Jaekel et al., 2012). The data presented herein lack the resolution to conclusively address whether archaeal phylotypes directly mediate or are members of consortia that perform the anaerobic oxidation of short-chain alkanes other than AOM.

The collective results presented here shed light on the potential anaerobic metabolism of short-chain alkanes linked to SR in the hydrothermal vent sediments of MV, Juan de Fuca Ridge. Substantial oxidation of $\mathrm{C}_{1}-\mathrm{C}_{4}$ occurs up to $75^{\circ} \mathrm{C}$. The coupling of $\mathrm{C}_{2}-\mathrm{C}_{4}$ with $\mathrm{SR}$ over the in situ temperature range may impact $\mathrm{AOM}$ and the oxidation of other hydrocarbons, as highlighted by the preferential degradation of $\mathrm{C}_{3}$ at $55^{\circ} \mathrm{C}$. Such microbial communities may play a substantial role in carbon and sulfur cycling at hydrothermal systems on a global-scale. Future studies should expand upon other environmental conditions that may regulate the anaerobic oxidation of $\mathrm{C}_{2}-\mathrm{C}_{4}$ alkanes in hydrothermal sediments and should further characterize the in situ abundance and activity of the putative thermophilic alkane-degrader SRB lineage.

\section{CONTRIBUTIONS}

Melissa M. Adams, Peter R. Girguis, and Arpita Bose designed the research. Melissa M. Adams, Peter R. Girguis, and Adrienne L. Hoarfrost directed the in situ collections and measurements. Melissa M. Adams, Adrienne L. Hoarfrost, and Arpita Bose conducted the batch reactor incubations and geochemical analyses. Samantha B. Joye performed the sulfate consumption measurements. Melissa M. Adams directed and analyzed the 


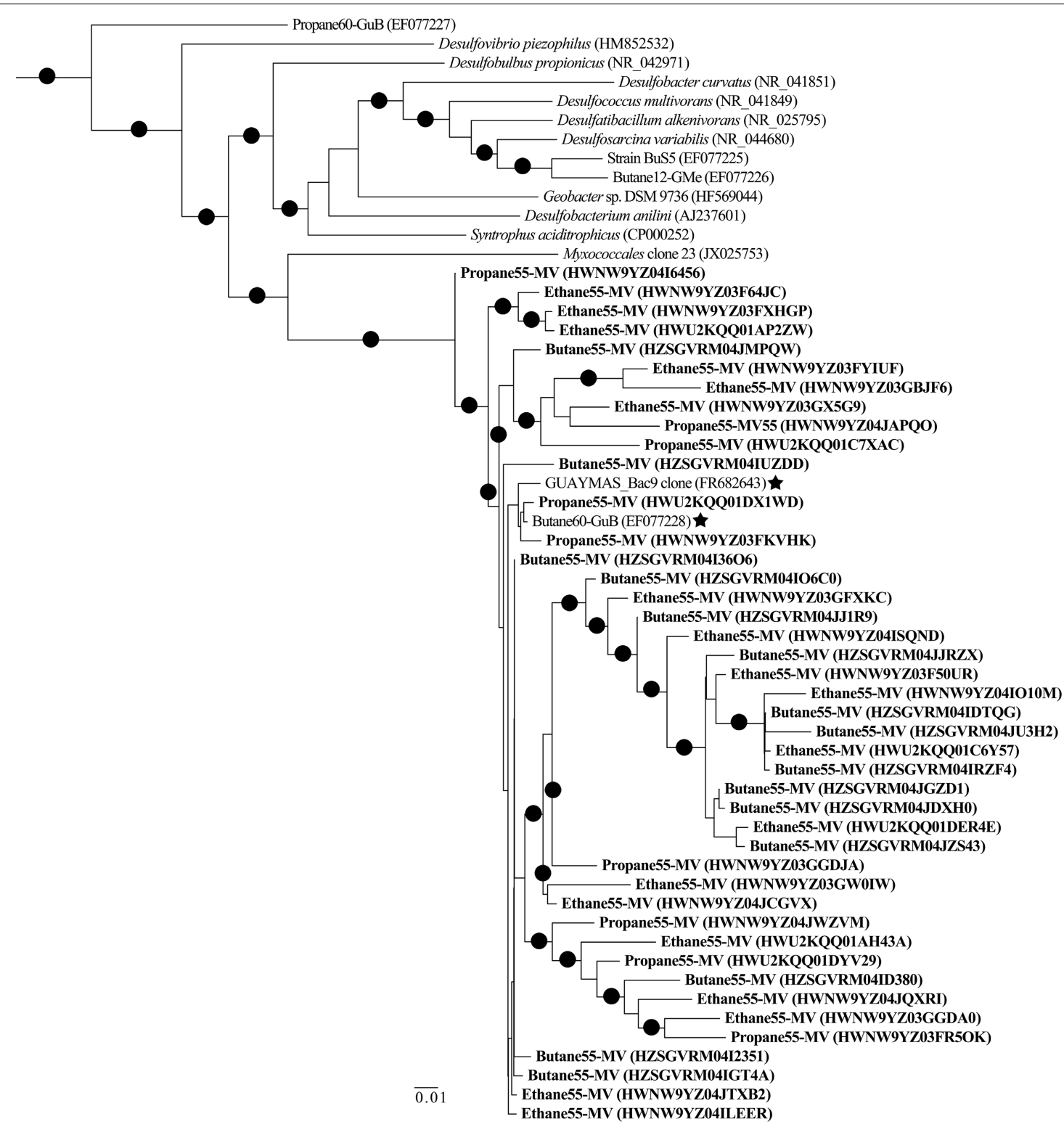

FIGURE 4 | Maximum-likelihood phylogenetic tree illustrating the relationships of selected 16S rRNA Deltaproteobacterial sequences recovered from Middle Valley sediments to Deltaproteobacterial sequences and uncultured environmental phylotypes from NCBI non-redundant database. Representative sequences from Middle Valley sediments incubated in batch reactors at $55^{\circ} \mathrm{C}$ with ethane (Ethane55-MV), propane (Propane55-MV), and butane (Butane55-MV) in bold. The most closely related environmental phylotypes from Guaymas Basin sediment sequences have been marked $(\star)$. The tree was rooted to Archaeoglobus profundus DSM 5631(NR_074522). Scale $=0.01$ substitutions per site. alkane consumption, sulfide production, and all rate calculations. Melissa M. Adams performed the molecular analyses. Melissa M. Adams and Peter R. Girguis wrote the manuscript with input from Samantha B. Joye, Arpita Bose, and Adrienne L. Hoarfrost.

\section{ACKNOWLEDGMENTS}

We acknowledge the expert assistance of the R/V Atlantis crews and the pilots and team of the DSV Alvin for enabling both the collection of temperature data and sediments used in our experiments. We thank Jennifer Delaney, Kimberly Hunter, Johanna Schweers, Ryan Sibert, and Charles Vidoudez for providing assistance with various aspects of the experiments, sample processing, and/or data interpretation. We also thank David Johnston and Andrew Knoll for constructive input during the preparation of this manuscript. This project was supported by grants from the National Science Foundation (NSF MCB 0702504 to Peter R. Girguis), the National Aeronautics and Space Administration (NASA ASTEP grant 0910169 to C. Scholin and Peter R. Girguis), NASA ASTEP grant NNX07AV51G to A. Knoll and Peter R. Girguis, the Advanced Research Projects Agency - Energy (ARPA-E), U.S. Department of Energy (DoE) (DE-AR 0000079 to Peter R. Girguis), and NSF MCB 0702080 to Samantha B. Joye. 


\section{REFERENCES}

Acosta-Martínez, V., Dowd, S. E., Bell, C. W., Lascano, R., Booker, J. D., Zobeck, T. M., et al. (2010). Microbial community composition as affected by dryland cropping systems and tillage in a semiarid sandy soil. Diversity 2, 910-931.

Alperin, M. J., Reeburgh, W. S., and Whiticar, M. J. (1988). Carbon and hydrogen isotope fractionation resulting from anaerobic methane oxidation. Global Biogeochem. Cycles 2, 279-288.

Ames, D. E., Franklin, J. M., and Hannington, M. H. (1993). Mineralogy and geochemistry of active and inactive chimneys and massive sulfide, Middle Valley, northern Juan de Fuca Ridge: an evolving hydrothermal system. Can. Mineral. 31, 997-1024.

Barns, S. M., Fundyga, R. E., Jeffries, M. W., and Pace, N. R. (1994). Remarkable archaeal diversity detected in a Yellowstone National Park hot spring environment. Proc. Natl. Acad. Sci. U.S.A. 91, 1609-1613.

Beal, E. J., House, C. H., and Orphan, V. J. (2009). Manganese- and irondependent marine methane oxidation. Science 325, 184-187.

Boetius, A., Ravenschlag, K., Schubert, C. J., Rickert, D., Widdel, F., Gieseke, A., et al. (2000). A marine microbial consortium apparently mediating anaerobic oxidation of methane. Nature 407, 623-626.

Boreham, C. J., Hope, J. M., and Hartung-Kagi, B. (2001). Understanding source, distribution and preservation of Australian natural gas: a geochemical perspective. Aust. Prod. Pet. Explor. Assoc. J. 41, 523547.

Bowles, M. W., Samarkin, A., Bowles, K. M., and Joye, S. B. (2011). Weak coupling between sulfate reduction and the anaerobic oxidation of methane in methane-rich seafloor sediments during ex situ incubation. Geochim. Cosmochim. Acta 75, 500-519.

Butterfield, D. A., Massoth, G. J., McDuff, R. E., Lupton, J. E., and Lilley, M. D. (1990). Geochemistry of hydrothermal fluids from Axial Seamount hydrothermal emissions study vent field, Juan-de-Fuca Ridge - Subseafloor boiling and subsequent fluid-rock interaction. J. Geophys. Res. Solid 95, 12895-12921.

Butterfield, D. A., McDuff, R. E., MottlM, J., Lilley, M. D., Lupton, J. E., and Massoth, G. J. (1994). Gradients in the composition of hydrothermal fluids from the Endeavour segment vent field: phase separation and brine loss. J. Geophys. Res. 99, 9561-9583.

Cline, J. D. (1969). Spectrophotometric determination of hydrogen sulfide in natural waters. Limnol. Oceanogr.14, 454-458.

Cruse, A. M., and Seewald, J. S. (2006). Geochemistry of lowmolecular weight hydrocarbons in hydrothermal fluids from Middle Valley, northern Juan de Fuca Ridge. Geochim. Cosmochim. Acta 70, 2073 2092.

Cruse, A. M., Seewald, J. S., Saccocia, P. J., and Zierenberg, R. A. (2008). "Geochemistry of hydrothermal fluids from Middle Valley, northern Juan de Fuca Ridge: temporal variability, subsurface conditions and equilibration during upflow," in Magma to Microbe: Modeling Hydrothermal Processes at Oceanic Spreading Ridge, eds R. Lowell and J. S. Seewald (Washington: AGU Monograph Series), 178 , 145-166.

Cruse, A. M., and Seewald, J. S. (2010). Low-molecular weight hydrocarbons in vent fluids from the Main Endeavour Field, northern Juan de Fuca Ridge. Geochim. Cosmochim. Acta 74, 6126-6140.

Conrad, R. (2009). The global methane cycle: recent advances in understanding the microbial processes involved. Environ. Microbiol. Rep.1, 285-292.

Davis, E. E., and Fisher, A. T. (1994). "On the nature and consequences of hydrothermal circulation in the Middle Valley sedimented rift: inferences from geophysical and geochemical observations, Leg 139," in Proceedings of the Ocean Drilling Program Scientific Results, Vol. 139, eds M. J. Mottl, E. E. Davis, A. T. Fisher, and J. F. Slack. (College Station: Ocean Drilling Program), 695-717.

Dojka, M. A., Hugenholtz, P., Haack, S. K., and Pace, N. R. (1998). Microbial diversity in a hydrocarbon- and chlorinatedsolvent-contaminated aquifer undergoing intrinsic bioremediation. Appl. Environ. Microbiol. 64, 3869-3877.

Dowd, S. E., Callaway, T. R., Wolcott, R. D., Sun, Y., McKeehan, T., Hagevoort, R. G., et al. (2008). Evaluation of the bacterial diversity in the feces of cattle using 16S rDNA bacterial tag-encoded FLX amplicon pyrosequencing (bTEFAP). BMC Microbiol. 8:125. doi: 10.1186/1471-2180-8-125

Elshahed, M. S., Najar, F. Z., Roe, B. A., Oren, A., Dewers, T. A., and Krumholz, L. R. (2004). Survey of archaeal diversity reveals an abundance of halophilic archaea in a low-salt, sulfide- and sulfur-rich spring. Appl. Environ. Microbiol. 70, 2230-2239.

Formolo, M. J., Lyons, T. W., Zhang, C., Kelley, C., Sassen, R., Horita, J., et al. (2004). Quantifying carbon sources in the formation of authigenic carbonates at gas hydrate sites in the Gulf of Mexico. Chem. Geol. 205, 253-264.

Gieg, L. M., Kolhatkar, R. V., McInerney, M. J., Tanner, R. S., Harris, S. H. Sublette, K. L., et al. (1999). Intrinsic bioremediation of petroleum hydrocarbons in a gas condensatecontaminated aquifer. Environ. Sci. Technol. 33, 2550-2560.

Girguis, P. R., Orphan, V. J., Hallam, S. J., and DeLong, E. F. (2003). Growth and methane oxidation rates of anaerobic methanotrophic archaea in a continuous flow reactor bioreactor. Appl. Environ. Microbiol. 69, 5492-5502.

Goodfellow, W. D., and Blaise, B. (1988). Sulfide formation and hydrothermal alteration of hemipelagic sediment in Middle Valley, northern Juan de Fuca Ridge. Can. Mineral. 26, 675-696.

Hinrichs, K., Hayes, J., Bach, W., Spivack, A., Hmelo, L., Holm, N., etal. (2006). Biological formation of ethane and propane in the deep marine subsurface. Proc. Natl. Acad. Sci. U.S.A. 103, 14684-14689.

Hoehler, T., Alperin, M., and Albert, D. (1994). Field and laboratory studies of methane oxidation in anoxic marine sediment: evidence for a methanogen-sulfate reducer consortium. Global Biogeochem. Cycles 8, 451-463.

Merkel, A. Y., Huber, J. A., Chernyh, N. A., Bonch-Osmolovskaya, E. A., and Lebedinsky, A. V. (2013). Detection of putatively thermophilic anaerobic methanotrophs in diffuse hydrothermal vent fluids. Appl. Environ. Microbiol. 79, 915-923.

Milucka, J., Ferdelman, T. G., Polerecky, L., Franzke, D., Wegener, G., Schmid, M., et al. (2012). Zerovalentsulphur is a key intermediate in marine methane oxidation. Nature 491, 541-546.

Jaekel, U., Musat, N., Adam, B. Kuypers, M., Grundmann, O., and Musat, F. (2012). Anaerobic degradation of propane and butane by sulfate-reducing bacteria enriched from marine hydrocarbon cold seeps. ISME J. 1-11.

Joye, S. B., Boetius, A., Orcutt, B., Montoya, J., Schulz, H., Erickson, M., et al. (2004). The anaerobicoxidation of methane and sulfate reduction in sediments from Gulf of Mexico cold seeps. Chem. Geol. 205, 219-238.

Jorgensen, B. B., Isaksen, M. F., and Jannasch, H. W. (1992). Bacterial sulfate reduction above $100^{\circ} \mathrm{C}$ in deepsea hydrothermal vent sediments. Science 258, 1756-1757.
Kellermann, M. Y., Wegener, G., Elvert, M., Yoshinaga, M. Y., Lin, Y. S., Holler, T., et al. (2012). Autotrophy as a predominant mode of carbon fixation in anaerobic methaneoxidizing microbial communities. Proc. Natl. Acad. Sci. U.S.A. 109, 19321-19326.

Kimura, H., Mori, K., Yamanaka, T., and Ishibash, J. I. (2013). Growth temperatures of archaeal communities can be estimated from the guanine-plus-cytosine contents of 16S rRNA gene fragments. Environ. Microbiol. Rep. 5, 468-474.

Kniemeyer, O., Musat, F., Sievert, S. M., Knittel, K., Wilkes, H., Blumenberg, M., et al. (2007). Anaerobic oxidation of short-chain hydrocarbons by marine sulphate-reducing bacteria. Nature 449, 898-901.

Knittel, K., and Boetius, A. (2009). The anaerobic oxidation of methane - progress with an unknown process. Annu. Rev. Microbiol. 63, 311-334.

Larter, S. R., Head, I. M., Huang, H., Bennett, B., Jones, M., Aplin, A. C., et al. (2005). Biodegradation, gas destruction and methane generation in deep subsurface petroleum reservoirs: an overview. Q. J. Geol. Soc. Lond. 6, 633-639.

Lorenson, T. D., Kvenvolden, K. A., Hostettler, F. D., Rosenbauer, R. J., Orange, D. L., and Martin, J. B. (2002). Hydrocarbon geochemistry of cold seeps in the Monterey Bay National Marine Sanctuary. Mar. Geol. 181, 285-304

Mastalerz, V., de Lange, G. J., and Dahlmann, A. (2009). Differential aerobic and anaerobic oxidation of hydrocarbon gases discharged at mud volcanoes in the Nile deep- sea fan. Geochim. Cosmochim. Acta 73, 38493863.

Milkov, A. V. (2005). Molecular and stable isotope compositions of natural gas hydrates: a revised global dataset and basic interpretations in the context of geological settings. Org. Geochem. 36, 681-702.

Orphan, V., House, C., and Hinrichs, K. (2001). Methane-consuming archaea revealed by directly coupled isotopic and phylogenetic analysis. Science 293, 484-487.

Price, M. N., Dehal, P. S., and Arkin, A. P. (2010). FastTree 2 - approximately maximum-likelihood trees for large alignments. PLoS ONE 5:e9490. doi: 10.1371/journal.pone.0009490

Quince, C., Lanzén, A., Curtis, T. P., Davenport, R. J., Hall, N., Head, I. M., et al. (2009). Accurate determination of microbial diversity from 454 pyrosequencing data. Nat. Methods 6 , 639-641. 
Quistad, S. D., and Valentine D. L. (2011). Anaerobic propane oxidation in marine hydrocarbon seep sediments. Geochim. Cosmochim. Acta 75, 2159-2169.

Rabus, R., Wilkes, H., Behrends, A., and Armstroff, A. (2001). Anaerobic initial reaction of $\mathrm{n}$-alkanes in a denitrifying bacterium: evidence for (1-methylpentyl)succinate as initial product and for involvement of an organic radical in n-hexane metabolism. J. Bacteriol. 183, 17071715.

Rushdl, A. I., and Simonelt, B. R. T. (2002). Hydrothermal alteration of organic matter in sediments of the Northeastern Pacific Ocean: Part 1. Middle Valley, Juan de Fuca Ridge. Appl. Geochem. 17, 1401-1428.

Sassen, R., Roberts, H. H., Carney, R., Milkov, A. V., DeFreitas, D. A., Lanoil B., et al. (2004). Free hydrocarbon gas, gas hydrate, and authigenic minerals in chemosynthetic communities of the northern Gulf of Mexico continental slope: relation to microbial processes. Chem. Geol. 205, 195-217.

Savage, K. N., Krumholz, L. R., Gieg, L. M., Parisi, V. A., Suflita, J. M., Allen, J., et al. (2010). Biodegradation of low-molecular-weight alkanes under mesophilic, sulfatereducing conditions: metabolic intermediates and community patterns. FEMS Microbiol. Ecol. 72, 485-495.

Schink, B., and Friedrich, M. (1994). Energetics of syntrophic fatty acid oxidation. FEMS Microbiol. Rev. 15, 85-94.

Schloss, P. D., Westcott, S. L., Ryabin, T., Hall, J. R., Hartmann, M., Hollister, E. B., et al. (2009). Introducing mothur: open-source, platform-independent, communitysupported software for describing and comparing microbial communities. Appl. Environ. Microbiol. 75, 7537-7541.

Shen, Y., and Buick, R. (2004). The antiquity of microbial sulfate reduction. Earth Sci. Rev. 64, 243-272.

Valentine, D. L. (2011). Fates of methane in the Ocean. Ann. Rev. Mar. Sci. 3, 147-171.

Van Hamme, J., Singh, A., and Ward, O. (2003). Recent advances in petroleum microbiology. Microbiol. Mol. Biol. Rev. 67, 503-509.

Von Damm, K. L., Oosting, S. E., Kozlowski, R., Buttermore, L. G., Colodner, D. C., Edmonds, H. N., et al. (1995). Evolution of East Pacific Rise hydrothermal vent fluids following a volcanic eruption. Nature 375 47-50.

Wang, Z., Xu, Y., Zhao, J., Li, F., Gao, D., and Xing, B. (2011). Remediation of petroleum contaminated soils through composting and rhizosphere degradation. J. Hazard. Mater. 190 677-685.

Wankel, S. D., Adams, M. M. Johnston, D. T., Hansel, C. M., Joye, S. B., and Girguis, P. R. (2012). Anaerobic methane oxidation in metalliferous hydrothermal sediments: influence on carbon flux and decoupling from sulfate reduction. Environ. Microbiol. 14 2762-2740.

Wankel, S. D., Germanovich, L. N., Lilley, M. D., Genc, G., DiPerna, C. J., Bradley, A. S., et al. (2011). Influence of subsurface biosphere on geochemical fluxes from diffuse hydrothermal fluids. Nat. Geosci. 4, 461-468.

Webster, G., Newberry, C. J., Fry, J. C., and Weightman, A. J. (2003) Assessment of bacterial community structure in the deep sub-seafloor biosphere by $16 \mathrm{~S}$ rDNA-based techniques: a cautionary tale. J. Microbiol. Methods 55, 155-164.

Wegener, G., Niemann, H., Elvert, M., Hinrichs, K. U., and Boetius, A. (2008). Assimilation of methane and inorganic carbon by microbial communities mediating the anaerobic oxidation of methane. Environ. Microbiol. 10, 2287-2298.

Wenger, L. M., Davis, C. L., and Isaksen, G. H. (2002). Multiple controls on petroleum biodegradation and impact on oil quality. Soc. Petrol. Eng. Reserv. Eval. Eng. 5, 375-383.

Conflict of Interest Statement: The authors declare that the research was conducted in the absence of any commercial or financial relationships that could be construed as a potential conflict of interest.

Received: 15 February 2013; paper pending published: 26 March 2013; accepted: 17 April 2013; published online: 14 May 2013.

Citation: Adams MM, Hoarfrost AL, Bose A, Joye SB and Girguis PR (2013) Anaerobic oxidation of short-chain alkanes in hydrothermal sediments: potential influences on sulfur cycling and microbial diversity. Front. Microbiol. 4:110. doi: 10.3389/fmicb.2013.00110

This article was submitted to Frontiers in Extreme Microbiology, a specialty of Frontiers in Microbiology.

Copyright (c) 2013 Adams, Hoarfrost, Bose, Joye and Girguis. This is an openaccess article distributed under the terms of the Creative Commons Attribution License, which permits use, distribution and reproduction in other forums, provided the original authors and source are credited and subject to any copyright notices concerning any third-party graphics etc. 